\title{
Opportunities for Chemistry at the SwissFEL X-ray Free Electron Laser
}

\author{
Christopher J. Milne*, Paul Beaud, Yunpei Deng, Christian Erny, Rolf Follath, Uwe Flechsig, Christoph \\ P. Hauri, Gerhard Ingold, Pavle Juranic, Gregor Knopp, Henrik Lemke, Bill Pedrini, Peter Radi, and \\ Luc Patthey
}

\begin{abstract}
X-ray techniques have long been applied to chemical research, ranging from powder diffraction tools to analyse material structure to X-ray fluorescence measurements for sample composition. ${ }^{[1]}$ The development of high-brightness, accelerator-based X-ray sources has allowed chemists to use similar techniques but on more demanding samples and using more photon-hungry methods. X-ray Free Electron Lasers (XFELs) ${ }^{[2]}$ are the latest in the development of these large-scale user facilities, opening up new avenues of research and the possibility of more advanced applications for a range of research. The SwissFEL XFEL project at the Paul Scherrer Institute will begin user operation in the hard X-ray (2.1-12.4 keV) photon energy range in 2018 with soft X-ray (240-1930 eV) user operation to follow and here we will present the details of this project, it's operating capabilities, and some aspects of the experimental stations that will be particularly attractive for chemistry research. SwissFEL is a revolutionary new machine that will complement and extend the time-resolved chemistry efforts in the Swiss research community.
\end{abstract}

Keywords: SwissFEL $\cdot$ X-ray free electron laser

\section{Introduction}

Chemistry has long been a forwardlooking field, with its researchers constantly developing new tools and pushing the limits of current techniques to answer a broad range of research questions. Chemistry has rapidly adopted X-ray Free Electron Lasers (XFELs) as yet another research tool in their panoply of techniques, taking full advantage of these highly-specialized sources of high energy photons. XFEL techniques are often similar to those developed at third-generation synchrotron light sources, which include $\mathrm{X}$-ray spectroscopy, X-ray scattering, and $\mathrm{X}$-ray imaging methods. ${ }^{[3]}$ The fundamental difference between the properties of the two facilities is that whereas a storage ring produces a quasi-continuous beam of $\mathrm{X}$-rays for experiments, XFELs produce short bursts of very intense X-rays at periodic intervals. A facility such as SwissFEL operates at a repetition rate of $100 \mathrm{~Hz}$, pro-

\footnotetext{
${ }^{*}$ Correspondence: Dr. C. J. Milne

SwissFEL

Paul Scherrer Institute

$\mathrm{CH}-5232$ Villigen-PSI

E-mail: chris.milne@psi.ch

https://www.psi.ch
}

ducing 50 fs duration X-ray pulses with over $1 \mathrm{~mJ}$ of energy per pulse $\left(10^{12}\right.$ photons/pulse). These properties make XFELs ideal for certain types of experiments, and in some cases have driven the development of entirely new techniques, such as nonlinear X-ray techniques. ${ }^{[4]}$ In the following sections, we will introduce the details of the SwissFEL machine, beamlines and experimental stations, concluding with some examples of how the facility will be used for chemistry research.

\section{Facility}

The SwissFEL is located at the Paul Scherrer Institute (Villigen, Switzerland), which is the home to other large-scale user facilities including the Swiss Light Source, a third-generation synchrotron light source, $\mathrm{S} \mu \mathrm{S}$, the Swiss Muon Source, SINQ, the Swiss Spallation Neutron Source, and HIPA, the high-intensity proton accelerator. SwissFEL is located in the forest on the East side of the Aare river, with the building located partially underground. The building itself is just under $1 \mathrm{~km}$ long, starting from the injector and ending at the experimental hall. The facility includes large areas for the experiments, including $692 \mathrm{~m}^{2}$ for the three soft X-ray Athos beamlines and instruments, and three large hard X-ray hutches for three experimental stations, which are located on the three Aramis beamlines (see Fig. 1 for a schematic layout of the experimental areas). In addition to the experimental hutches there will be laboratory space for chemical and biological sample preparation, and techni- cal work areas for instrument assembly and testing. Optical lasers will be available for both Athos and Aramis experiments, with the laser infrastructure installed directly in the soft X-ray experimental hall and on the first floor above the hard X-ray experimental hutches (see Fig. 1).

The SwissFEL accelerator scheme is shown in Fig. 2. The initial installation of the Aramis hard X-ray branch was completed in 2017, and is scheduled to begin user operation in 2018. It consists of the electron gun and injector, followed by three linear accelerator (linac) stages to accelerate the electrons to their highest energy of $5.8 \mathrm{GeV}$. In order to achieve the upper target X-ray photon energy of $12.4 \mathrm{keV}$ (1 $\AA$ ) this requires a low-emittance electron beam. After the electron acceleration stages the photons are generated by 12 in-vacuum undulator modules with variable gap. ${ }^{5,6]}$ This variable gap allows the photon energy to be easily changed, which is important for X-ray spectroscopy experiments. ${ }^{[7]}$ The soft X-ray Athos branch of the accelerator uses the first two Aramis linac stages to achieve an electron energy of $3 \mathrm{GeV}$, and a fast electron kicker to direct the beam into the Athos undulators. Linac 3 can be used to accelerate or decelerate the electrons, allowing it to cover the full electron energy range $(2.1-5.8 \mathrm{GeV})$ while maintaining a stable electron energy for the Athos branch. The Athos undulator section allows full polarization control over the X-rays while still allowing for easy scanning of the photon energy, while the Aramis undulators produce horizontally polarized photons, also tunable over a wide energy range. 
SwissFEL will operate Aramis initially using two electron charge modes which will allow users to choose between high perpulse X-ray flux (200 pC, 50 fs FWHM) or short pulse duration ( $10 \mathrm{pC}, 1$ fs FWHM). In the future several more advanced operation modes are anticipated including broad X-ray bandwidths $(5-7 \%),{ }^{[8]}$ attosecond pulse durations (100 as), and two-pulse operation with tuneable pulse energies and time delays. ${ }^{[9]}$ The Athos branch has similar advanced capabilities, but with some additional possibilities introduced by the installation of magnetic chicanes between the undulator modules, the so-called CHIC mode of operation. ${ }^{[10,11]}$ In final operation capacity SwissFEL will be able to operate both Athos and Aramis simultaneously by producing and accelerating two electron bunches separated by $28 \mathrm{~ns}$, then using a fast electron kicker to direct one of the bunches into the Athos accelerator branch. The SwissFEL design parameters are given in Table 1.

\section{Beamlines}

The hard X-ray branch of SwissFEL consists of three planned beamlines, each delivering the FEL radiation into three experimental hutches. ${ }^{[12]}$ The initial phase of operation will cover the first two experimental hutches, with the third planned for installation in the coming years. The optics scheme for the beamlines is shown in Fig. 3.

The beamlines are physically separated by the use of horizontal offset mirrors that direct the XFEL beam either to the left or the right, allowing for three different beam trajectories. Each beamline will be capable of operating in either so-called pink beam mode, with the full XFEL X-ray spectrum delivered to the experiment $(0.05-7 \%)$, or monochromatic mode where only a narrow $\mathrm{X}$-ray bandwidth is used (e.g. $0.015 \%)$.

Table 1. SwissFEL design parameters covering both the soft and hard X-ray branches. Values in red are advanced operation modes.

\begin{tabular}{l|l}
\hline Description & Range \\
\hline Wavelength & $1 \AA$ to $70 \AA$ \\
\hline Photon energy & 0.24 to $12.4 \mathrm{keV}$ \\
\hline Photons/pulse @ $1 \AA$ & $10^{11}$ \\
\hline Pulse duration (FWHM) & 1 to 50 fs $(100 \mathrm{as})$ \\
\hline Spectral bandwidth & $0.05-0.16 \%(5-7 \%)$ \\
\hline Maximum electron energy & $5.8 \mathrm{GeV}$ \\
\hline Electron bunch charge & $10-200 \mathrm{pC}$ \\
Repetition rate & $100 \mathrm{~Hz}$
\end{tabular}
accelerator, $\mathrm{BC}=$ bunch compressor.

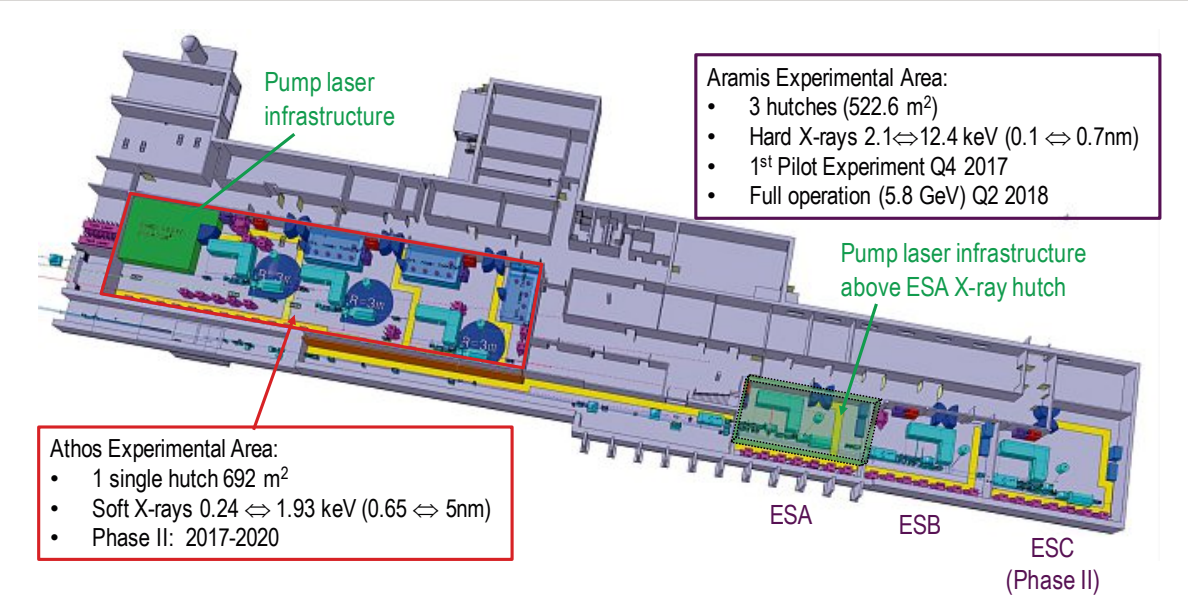

Fig. 1. SwissFEL experimental hutch layout. The hard X-ray experimental stations ESA and ESB will be ready for user operation in 2018, with ESC and Athos coming online in the following period. The X-rays come from the accelerator tunnel, which is to the left on the above layout, and move through the above building layout from left to right.

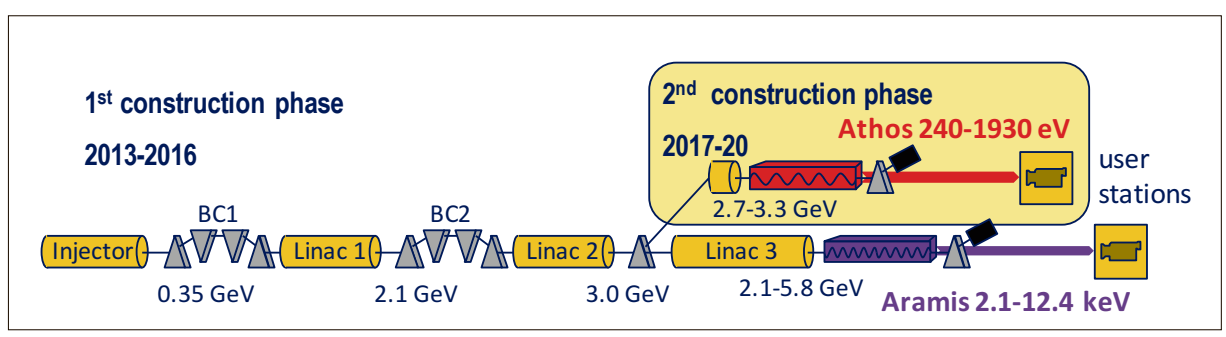

Fig. 2. SwissFEL accelerator design. The hard X-ray Aramis branch will begin user operation in 2018 with the soft X-ray Athos branch installation to begin in 2017. Legend: Linac = linear

Through the use of vertical mirrors both of these modes share the same beam path, allowing all the downstream optics, diagnostics and experimental positions to remain unchanged when switching between modes. When using monochromatic mode the X-ray beam direction will remain unchanged when scanning the X-ray energy through the use of fixed-exit monochromator designs. Each monochromator has three crystal pairs mounted, which will include $\mathrm{Si}(111), \mathrm{Si}(311)$ and $\mathrm{InSb}(111)$, which will

cover the full X-ray photon energy range with varying energy resolution. Aramis 1 has vertically deflecting harmonic rejection mirrors following the monochromator to remove the higher-order X-ray harmonics when operating in the lower range of X-ray photon energies (2-5 keV) where significant harmonic contamination can be especially problematic for spectroscopic measurements. ${ }^{[12]}$ The beamlines are equipped with flexible Kirkpatrick-Baez focussing mirrors, allowing the X-ray focus to be changed depending on the experimental requirements $(1.5-100 \mu \mathrm{m})$. Because of the achromatic nature of these optics they will not need to be adjusted when changing the $\mathrm{X}$-ray photon energy. Future possible upgrades to the beamlines include compound refractive lenses for simpler focussing requirements and phase-retarders to be able to control the hard X-ray polarization on the sample. ${ }^{[13]}$

In addition to the X-ray optics the beamlines also include several different diagnostics elements to report on the properties of the X-ray beam. Depending on their application they can be destructive, precluding any other measurement from taking place with the XFEL beam, and online, providing information concurrent to an experiment for every X-ray pulse. The information recorded for every pulse in- 


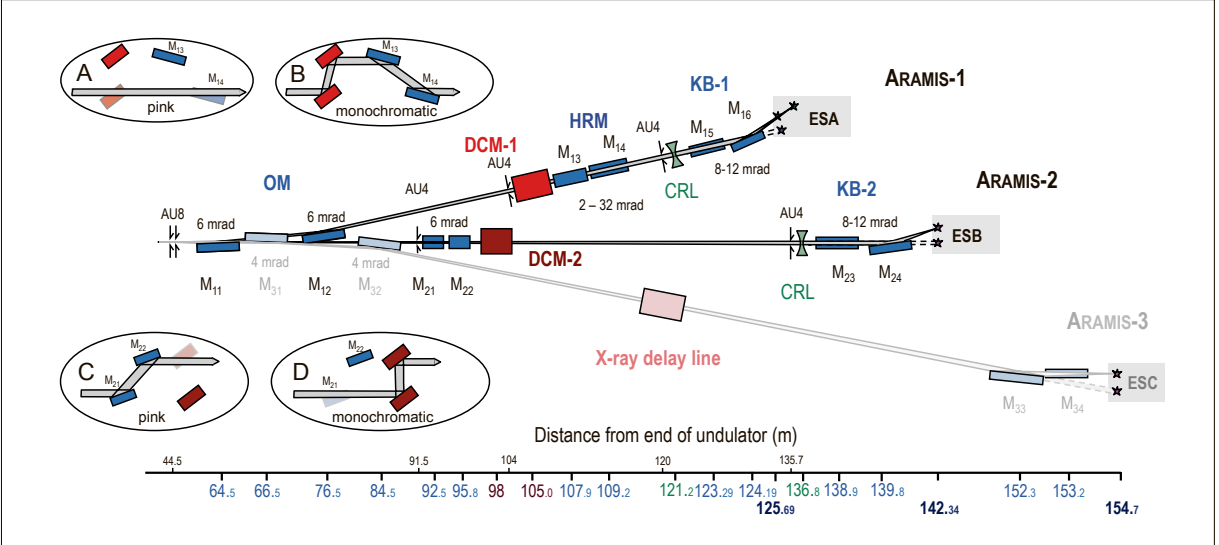

Fig. 3. Layout of the Aramis hard X-ray beamlines. Aramis-1 (ESA) and Aramis-2 (ESB) will be ready for users in 2018, while Aramis 3 (ESC) will be installed in the following period. Oval insets indicate the two possible beam paths for Aramis-1 (A, B) and Aramis-2 (C, D). Legend: $M=$ mirror, $\mathrm{DCM}=$ double-crystal monochromator, $\mathrm{KB}=$ Kirkpatrick-Baez focussing mirrors, $\mathrm{OM}=$ offset mirror, $\mathrm{CRL}=$ compound refractive lenses, pink = broad $\mathrm{X}$-ray spectrum. The $\mathrm{X}$ axis coordinates represent the distance of the optical elements from the end of the undulators.

cludes the X-ray spectrum, ${ }^{[14,15]}$ the $\mathrm{X}$-ray pulse energy and the X-ray beam position. ${ }^{[16,17]}$ When pump-probe experiments are performed a specialized timing diagnostic is used to provide information on the relative time-delay between the optical laser excitation pulse and the probe X-ray pulse. ${ }^{[18,19]}$ This information allows the experiment to achieve the best time resolution possible and corrects for the various timing instabilities that can affect these types of experiments. ${ }^{[20]}$ The goal of the timing diagnostic is to provide $10 \mathrm{fs}$ time resolution for the experiments.

\section{Laser}

In order to fully take advantage of the femtosecond time resolution the XFEL is capable of providing, each experimental station has access to a highly reliable commercial laser system. These laser systems are based on Ti:Sa technology and provide $20 \mathrm{~mJ}, 35 \mathrm{fs}$ pulses at $100 \mathrm{~Hz} .^{[21]}$ These lasers are located in a climate controlled room on the first floor above the ESA $\mathrm{X}$-ray hutch (see Fig. 1). The laser is then

Table 2. Laser pulse energies delivered to the experiment assuming $8 \mathrm{~mJ}$ and $30 \mathrm{fs}$ pump laser values delivered to the OPA. Numbers are extracted from ref. [21].

\begin{tabular}{|l|l|l|}
\hline Wavelength & Pulse energy & Pulse duration (FWHM) \\
\hline $240-295 \mathrm{~nm}$ & $>26 \mu \mathrm{J}$ at peak & $<90 \mathrm{fs}$ \\
\hline $290-480 \mathrm{~nm}$ & $>40 \mu \mathrm{J}$ at peak & $36-60 \mathrm{fs}$ \\
\hline $475-533 \mathrm{~nm}$ & $>466 \mu \mathrm{J}$ at peak & $30-45 \mathrm{fs}$ \\
\hline $533-600 \mathrm{~nm}$ & $>306 \mu \mathrm{J}$ at peak & $30-45 \mathrm{fs}$ \\
\hline $600-1160 \mathrm{~nm}$ & $>320 \mu \mathrm{J}$ at peak & $30-45 \mathrm{fs}$ \\
\hline $1160-2600 \mathrm{~nm}$ & $>2000 \mu \mathrm{J}$ at peak & $36-45 \mathrm{fs}$ \\
\hline
\end{tabular}

imental stations have similar beamline capabilities, as illustrated in the previous section, but the instruments located at the experimental stations are focussed on emphasizing different X-ray techniques. The conceptual design reports for all instruments presented in this section are available on the SwissFEL website. ${ }^{[23]}$

\section{Experimental Station Alvra[24]}

The layout of the ESA experimental hutch is shown in Fig. 4. ESA is focussed primarily on two techniques: X-ray spectroscopy ${ }^{[7,25]}$ and Serial Femtosecond Crystallography (SFX). ${ }^{[26,27]} \mathrm{X}$-ray spectroscopy involves measuring the $\mathrm{X}$-ray transmission or X-ray fluorescence of a sample as a function of monochromatic X-ray energy. ${ }^{[3]}$ These measurements can provide information on the local electronic and geometric structure around the absorbing species. ${ }^{[25]}$ SwissFEL will be particularly suited for these types of experiments due to its variable-gap undulators ${ }^{[28,29]}$ which can easily scan the X-ray energy of the XFEL over a very wide range, allowing techniques such as X-ray absorption nearedge structure (XANES) and Extended $\mathrm{X}$-ray absorption fine structure (EXAFS) to be used. ${ }^{[25]} \mathrm{SFX}$ is a technique that has been developed for protein crystallography where a stream of small crystals is delivered into the focussed X-ray beam using a range of different injector techniques, and the diffraction pattern from each crystal is recorded on a large two-dimensional detector. ${ }^{[30]}$ Though the intense XFEL pulse destroys the crystal, because an ultrashort $\mathrm{X}$-ray pulse is used the diffraction occurs before the atoms have time to move from their lattice positions. ${ }^{[31,32]}$ SFX can resolve room-temperature protein structures to better than $2 \AA$ resolution on very small crystals, ${ }^{[26,30]}$ which expands the technique to include samples that are difficult to crystallize, such as membrane proteins. ${ }^{[33]}$ ESA has the additional capability of performing X-ray emission spectroscopy (XES) which uses X-ray diffraction from an analyser crystal to measure the scattered or fluorescence X-ray photons with high energy resolution. ${ }^{[34]}$ ESA uses short focal length crystals $(25 \mathrm{~cm})$ in a dispersive von Hamos geometry ${ }^{[35]}$ to measure a range of XES energies in a single measurement. This spectrometer can also be used for a variety of other scattering measurements include off-resonant techniques ${ }^{[36,37]}$ and inelastic $\mathrm{X}$-ray scattering (IXS).

These techniques will be applied at two instruments, which are located in line with the X-ray beam: ESA Prime and ESA Flex (see Fig. 4). Due to the flexible KB mirrors the X-rays can be focussed at either instrument, with the minimum focus of $1.5 \mu \mathrm{m}$ achieved at ESA Prime. Both instruments 


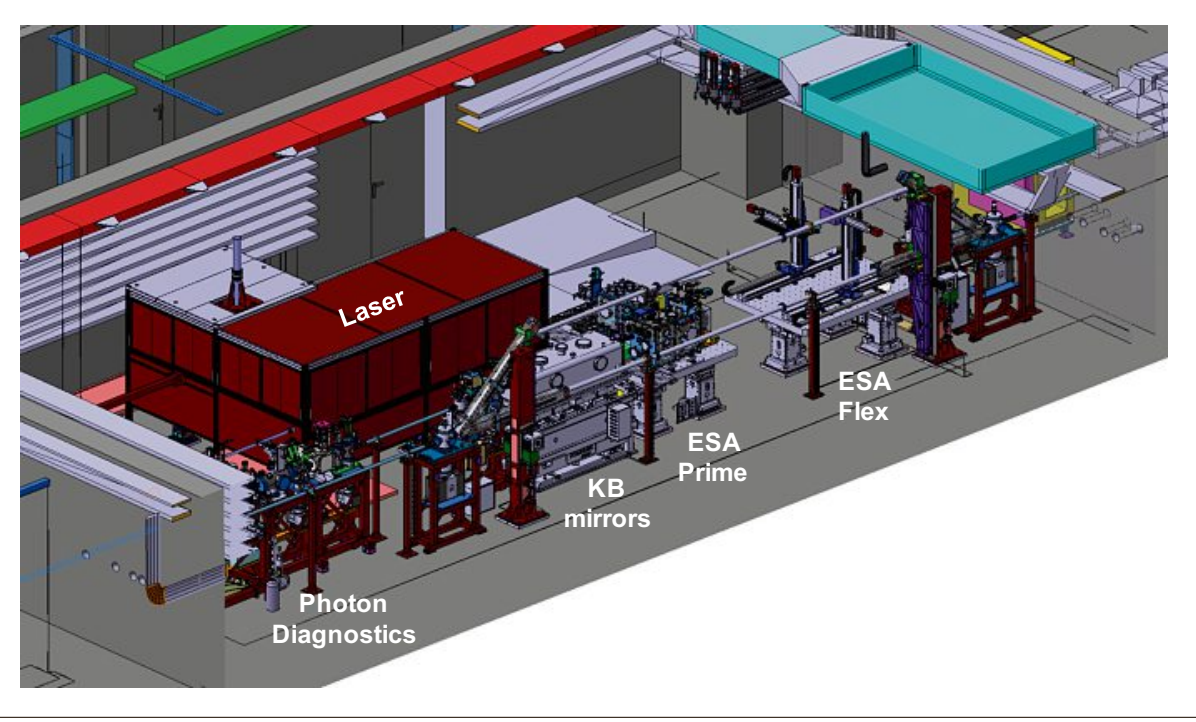

Fig. 4. Hutch layout for Experimental station A showing the location of the various elements within the hutch. The X-rays go through the hutch from left to right. Figure courtesy of Dominique Hauenstein.

can be used with the optical laser for pumpprobe experiments, with an anticipated time resolution of better than $50 \mathrm{fs} .{ }^{[19]} \mathrm{ESA}$ Prime has a chamber that can be operated under vacuum, $\mathrm{He}$, or neutral atmosphere and combines a large 2D Jungfrau scattering detector ${ }^{[38-40]}$ and a dual-crystal from a Hamos X-ray emission spectrometer. This allows experiments to be performed using both scattering and emission techniques simultaneously, which has proven to be a powerful combination for molecular ${ }^{[41,42]}$ and protein ${ }^{[43,44]}$ samples. The chamber has the possibility of using different types of sample injectors, including several specifically for SFX sample delivery. ${ }^{[45,46]}$ The expected achievable resolution of the crystallography measurements at $12.4 \mathrm{keV}$

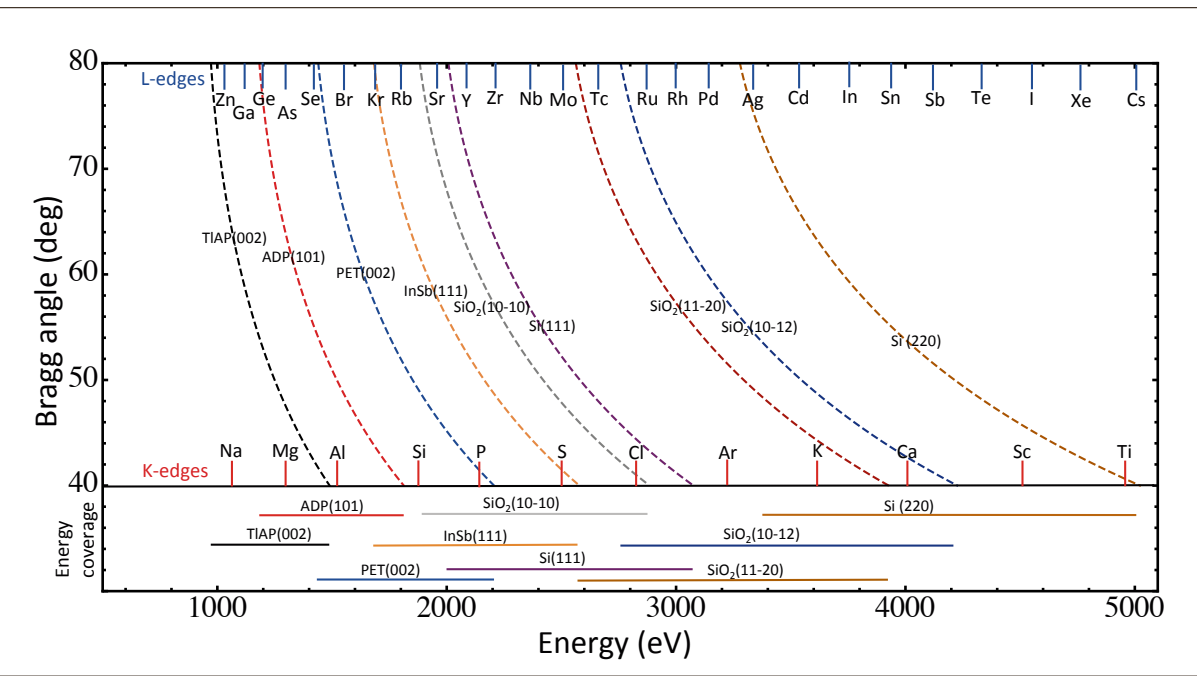

Fig. 5. The X-ray energy range covered by the ESA Prime X-ray spectrometer. The dashed lines are the various crystals available for use with the spectrometer, covering the full range of energies at the range of Bragg angles available in the spectrometer. The energies of various X-ray emission transitions are also marked to provide a sense as to what elements can be measured in this photon energy range. Figure courtesy of Jakub Szlachetko.
Bragg angles $\left(>85^{\circ}\right)$ and segmented X-ray crystals $^{[35]}$ this spectrometer is capable of $100 \mathrm{meV}$ energy resolution. Both instruments are shown in Fig. 6.

\section{Experimental Station Bernina}

The Aramis 2 beamline is very similar in scope to Aramis 1, making the X-ray properties available at ESB very similar to those available at ESA. The primary difference is longer focal length $\mathrm{KB}$ mirrors, providing a larger minimum $\mathrm{X}$-ray focus of $2.5 \mu \mathrm{m} .{ }^{[12]} \mathrm{ESB}$ is focussed primarily on solid state physics experiments, ${ }^{[47]}$ building upon the expertise acquired ${ }^{[48]}$ at the FEMTO laser-electron slicing source installed at the Swiss Light Source. ${ }^{[49,50]}$ The primary tool for this will be a six-circle hard X-ray Kappa-diffractometer (XRD) with a $1.5 \mathrm{M}$ Jungfrau $2 \mathrm{D}$ detector mounted on the detector arm, which is capable of both resonant and non-resonant diffraction experiments. In addition to this instrument the experimental station will have a general-purpose instrument (GPS) upon which users can mount or build their experimental setup. These instruments are mounted on a rail system transverse to the beam to allow them to be moved in and out of position, while maintaining the same X-ray focus position. Both instruments will have access to the optical laser for pump-probe experiments and a large-area 2D Jungfrau detector, which is mounted on a robot arm on the X-ray hutch ceiling to allow for flexible positioning. A specific focus for these instruments is the ability to use strong $\mathrm{THz}$ fields for sample excitation, ${ }^{[21,22]}$ which allow for direct excitation of lattice dynamics in the condensed phase. ${ }^{[51]}$ The layout of the ESB hutch is shown in Fig. 7.

In addition to the two instruments described above a third instrument will be in use at ESB. This instrument, named ESB$\mathrm{MX}$, is designed to perform protein crystallography measurements using samples on a solid support. ${ }^{[52]}$ This has the advantage of increasing the hit rate of the protein crystals, which is a restriction of the liquid jet delivery methods. ESB-MX will consist of a chamber filled with He to reduce X-ray background scatter and highspeed translation stages that are capable of positioning the samples to within $1 \mu \mathrm{m}$ accuracy at $100 \mathrm{~Hz}$. The X-ray crystallography measurements will be performed with the Jungfrau $16 \mathrm{M}$ detector on the ceiling-mounted robot arm. The instrument will include a robot for automated sample exchange, allowing for very high throughput measurements. This allows for two methods of operation: 1) pre-location of the protein crystals on the solid support, ${ }^{[53]}$ allowing pre-programming of the support trajectory upon insertion at ESB-MX, or 2) raster scanning of the support to efficiently 


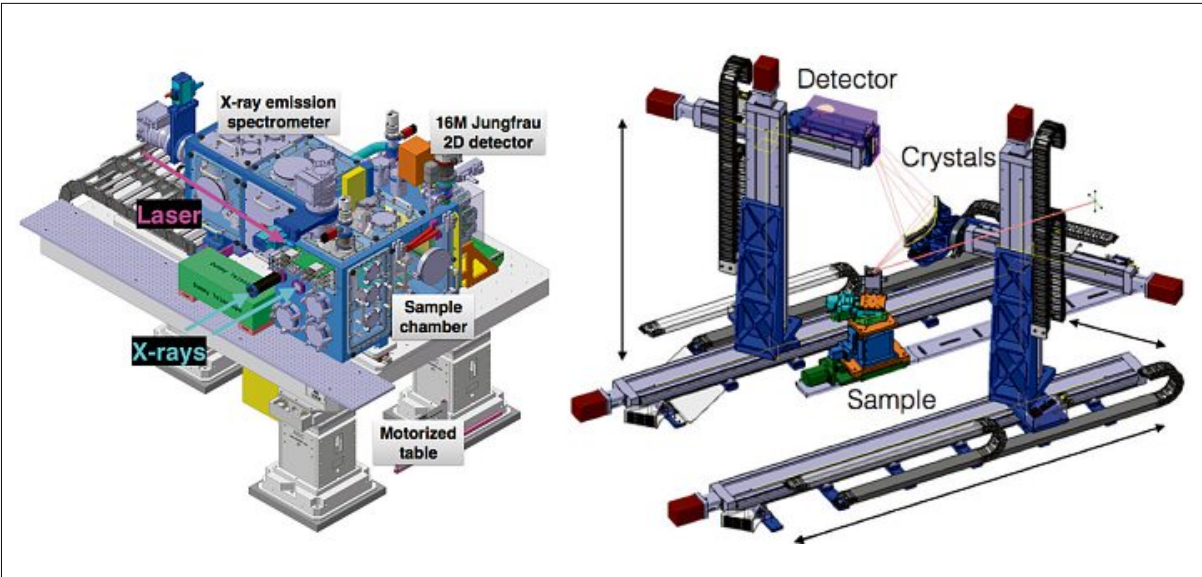

Fig. 6. Models of the two instruments available at ESA. Left: ESA Prime, a chamber capable of operating under vacuum, $\mathrm{He}$, or neutral atmosphere, which combines an X-ray emission spectrometer and a large 2D Jungfrau scattering detector for photochemistry or photobiology experiments. Right: ESA Flex, a flexible station for user-mounted experiments with a configurable high-energy resolution X-ray spectrometer.

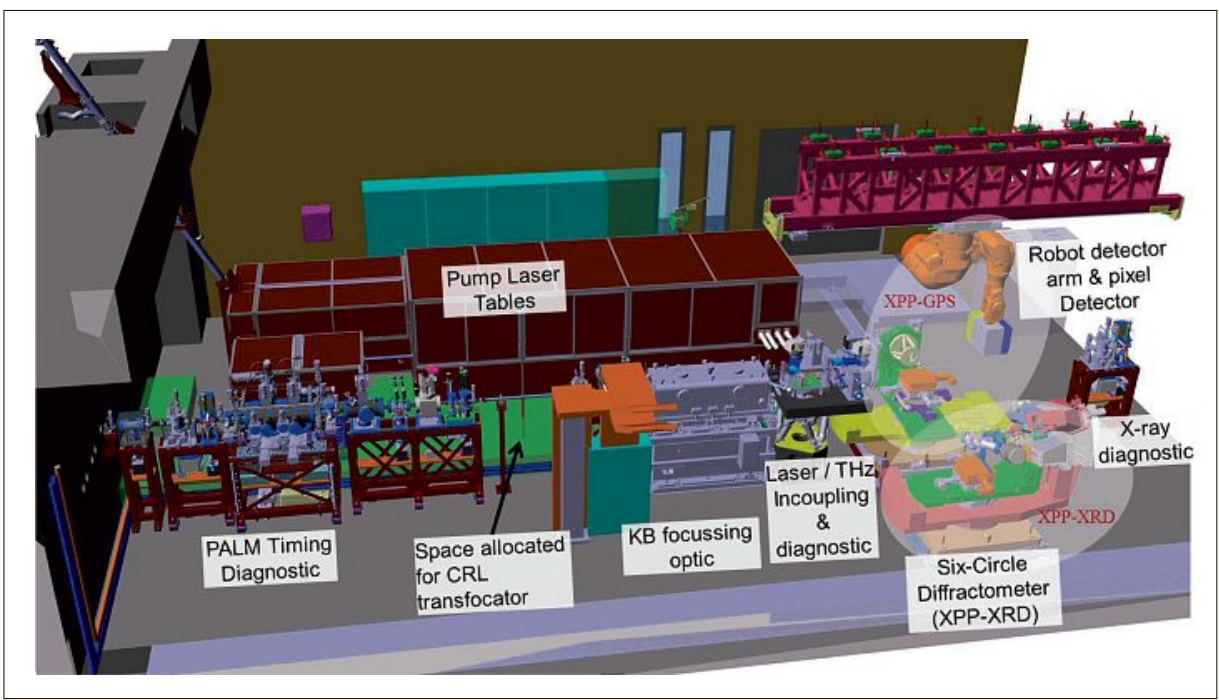

Fig. 7. Hutch layout for Experimental station B showing the location of the various elements within the hutch. The $\mathrm{X}$-rays go through the hutch from left to right.

measure randomly located crystals. In addition to techniques specific to solid support methods, ESB-MX will also be capable of more conventional protein crystallography methods, including goniometer rotation scans with large protein crystals. ${ }^{[54,55]}$ Fig. 8 shows how the temporary installation of ESB-MX will look in the ESB X-ray hutch.

\section{Chemistry at SwissFEL}

Chemistry is by necessity a multi-technique field of research since the samples themselves cover all forms of matter. In this section we will highlight some examples of how XFELs have been used to investigate chemical problems to illustrate how the SwissFEL experimental stations will be applied in the future.

\section{Aramis}

The field of photochemistry has long been investigated using time-resolved techniques. The ability to monitor energy relaxation pathways after photoexcitation using optical laser techniques has represented the core of femtochemistry research. ${ }^{[56]}$ This has recently been expanded to X-ray based structural techniques, including X-ray absorption spectroscopy ${ }^{[25]}$ and X-ray scattering, ${ }^{[57,58]}$ and X-ray techniques to probe electronic structural dynamics, such as X-ray emission spectroscopy. ${ }^{[25]}$ These techniques have often been combined since they provide complementary information on disordered systems, such as molecules or proteins in solution.

An example of how X-ray techniques have contributed to a better understanding of molecular photochemistry is in the field of spin-crossover molecular systems. ${ }^{[59,60]}$
The metal centres of these molecules (e.g. $\left.\mathrm{Fe}^{2+}, \mathrm{Fe}^{3+}, \mathrm{Co}^{2+}\right)$ can undergo a spin transition through changes of temperature, pressure, or by absorption of light. Early optical experiments had reported on the relaxation pathways of a prototypical $\mathrm{Fe}^{2+}$-based spin crossover complex (iron trisbipyridine, $\mathrm{Fe}^{\mathrm{II}}(\mathrm{bpy})_{3}$ ) with a large spin-state gap that could only be excited with visible light, ${ }^{[61]}$ but though the timescales of the dynamics were well established, the character of the electronic states involved were under debate. X-ray absorption experiments were able to identify the structure of the quintet high-spin state, ${ }^{[62]}$ and to establish that this structural change took place more quickly than previously assumed possible (<150 fs). ${ }^{[63]}$ Developments in UV transient-absorption spectroscopy were able to confirm this time-scale of population of the high-spin state and identify a vibrational mode coupled with this singlet-to-quintet spin state transition. ${ }^{[64]}$ The high spin state character was also confirmed using X-ray emission spectroscopy with 100 ps time resolution, [65] demonstrating this technique's sensitivity to the $\mathrm{Fe}$ spin state[66] but without the ability to achieve better time resolution to resolve the relaxation cascade. The open question was how the initial excitation into a singlet metal-to-ligand charge transfer state ( ${ }^{1}$ MLCT) could then populate a metal-centred quintet highspin state $\left({ }^{5} \mathrm{~T}\right)$ so quickly. Several intermediate states were suggested, including triplet MLCT and metal-centred states, ${ }^{[67]}$ but no conclusive explanation was forthcoming since no spin-sensitive experimental techniques were available with the required time resolution. In an attempt to understand the solvent interaction with these types of excited states, ${ }^{[68]}$ time-resolved experiments were performed combining both XES and wide-angle X-ray scattering (WAXS, also called X-ray diffuse scattering or XDS). ${ }^{69]}$ These results illustrated the complementary nature of XES, which provides information on the electronic state of the spin-crossover molecule, and WAXS, which provides information on both the structural changes in the molecule, but also on the solvent cage surrounding the molecule and the bulk solvent dynamics in response to the photoexcitation. With the introduction of XFELs both the XAS ${ }^{[70]}$ and combined XES/WAXS ${ }^{[41]}$ experiments were repeated with these new sources of high-brightness femtosecond $\mathrm{X}$-rays, though for technical reasons the time resolution was limited to around 500 fs, which restricted their ability to provide new information on the spin state relaxation cascade. The primary new information was that WAXS reported on ultrafast solvation changes around the excited molecule which corresponded to an increase in bulk solvent density on a timescale of $1 \mathrm{ps}$. The 


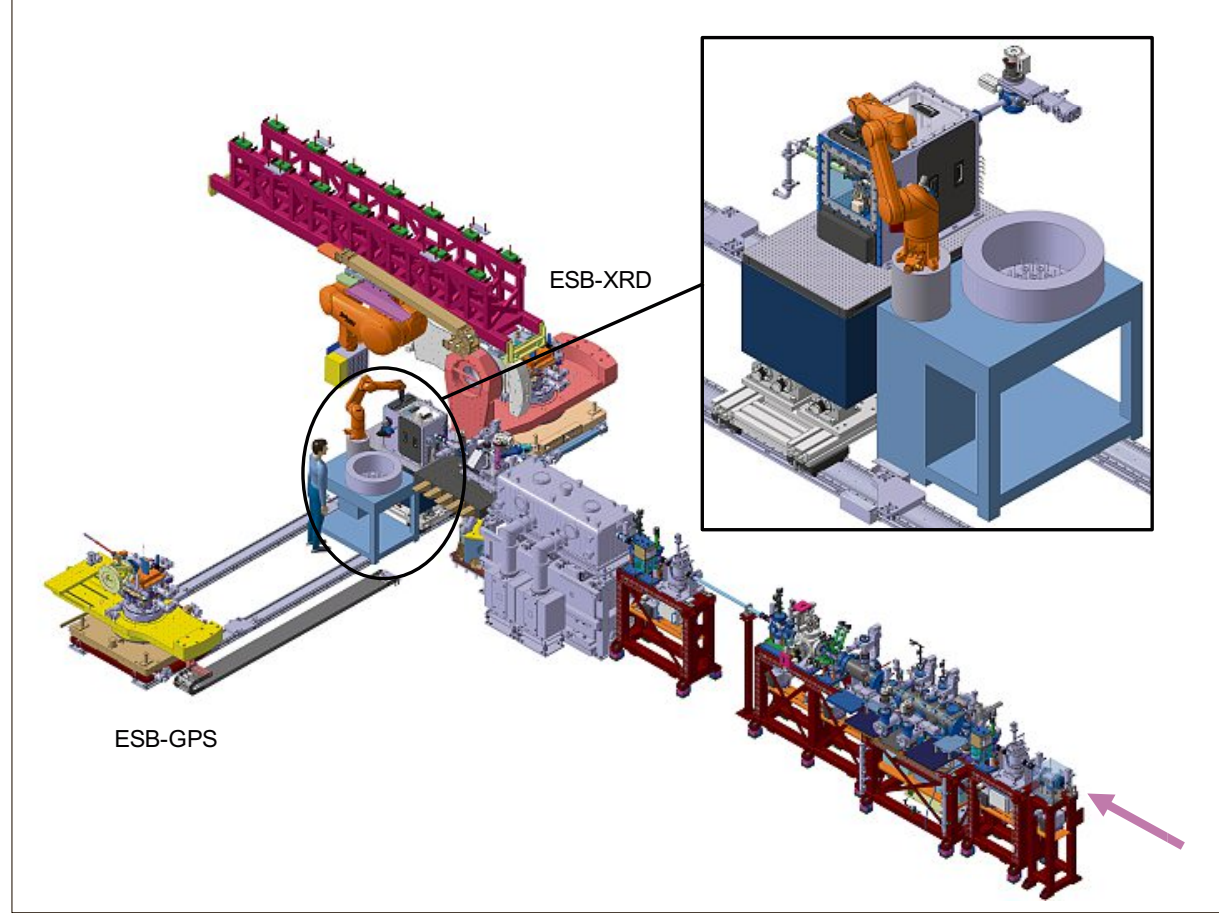

Fig. 8. ESB-MX installation in the ESB hutch positioned between the diffractometer (XRD) and general-purpose (GPS) instruments on the hutch rail system. X-rays propagate from right to left. Inset: Details of the ESB-MX installation including the sample chamber and robot sample changer. Figure courtesy of Jan Hora and Pirmin Boehler.

conclusion drawn was that upon spin state excitation the structural change caused the expulsion of two water molecules from the solvation shell around the molecule, in agreement with theoretical predictions. ${ }^{[71]}$ The most recent X-ray measurement to contribute to this discussion used XES with $150 \mathrm{fs}$ time resolution, courtesy of the development of a timing tool for X-raylaser jitter correction at LCLS. [72] These measurements were compared with XES measurements on reference compounds in various $\mathrm{Fe}$ spin- and oxidation states. The conclusions drawn were that at early times (50 fs) the spin-state was not purely a quintet, but more consistent with a triplet ligand-field excited state $\left({ }^{3} \mathrm{~T}\right)$. This result is not the final conclusion since subsequent optical results ${ }^{[73]}$ with even better time resolution indicate that at 50 fs the molecule is in the high-spin state, essentially precluding the ability of the molecule to relax through a ligand-field ${ }^{3} \mathrm{~T}$ unless this process was occurring on a timescale of 20 fs. This overview illustrates how the combination of ultrafast optical and X-ray techniques have been used to address the question of ultrafast spin-state excitation, a question which has still not been fully resolved and will require X-ray measurements with 20 fs time resolution or better.

Though here we have presented but a single research example these techniques have been applied to many different fields of investigation, including donor-bridge-acceptor complexes, ${ }^{[42]}$ intramolecular dynamics, ${ }^{[74,75]}$ and protein structural changes. ${ }^{[76-78]}$ ESA is designed expressly for these kinds of experimental techniques: combining X-ray spectroscopy with X-ray scattering with excellent time resolution. We anticipate that as these techniques become more mature and their analysis more routine, combined with the introduction of additional facilities capable of these experiments, ${ }^{[79]}$ photochemistry on species in solution will undergo an explosion of interest in the chemistry community. The solution-phase experiments will be complemented by the recent development of gas-phase molecular scattering techniques. ${ }^{[80,81]}$

Though a majority of hard X-ray chemistry experiments performed to date at XFELs have been as described above, there are several other opportunities at SwissFEL which can be envisioned. One aspect which has not been well-explored has been the ability to measure the photochemistry of molecular crystals. The main restriction to these experiments involves the sample damage inherent to XFEL measurements and the inability to refresh the solid sample easily. These problems have been overcome at storage rings ${ }^{[82]}$ and experiments have demonstrated their potential at XFELs. ${ }^{[83]}$ The ability to measure crystal structures using large protein crystals and moving to a new spot between FEL pulses has been demonstrated so it is clear that similar measurements on molecular crystals at SwissFEL using an instrument such as ESB-MX will be possible in the future. A second approach would be to take advantage of the development of viscous sample injectors, ${ }^{[45]}$ which allow crystals to be mixed into the delivery medium ${ }^{[84,85]}$ and then extruded from the injector into the XFEL beam. In addition to room-temperature structural measurements, this technique has also been demonstrated for time-resolved protein crystallography, ${ }^{[86,87]}$ which can undoubtedly be extended to molecular crystals as well. Preliminary experiments have already been demonstrated on a powder of a perovskite manganite in a cryo-cooled liquid ethanol jet, ${ }^{[88]}$ illustrating that SFX need not be restricted solely to protein crystals.

\section{Athos}

While the focus has initially been on the installation and commissioning of the hard X-ray branch of SwissFEL, the extension to the soft X-rays in the Athos branch has also been in development. A sophisticated undulator approach (CHIC[11]) ensures a flexible photon source for experiments, ${ }^{[9,10]}$ and a novel undulator design allows for easy control over polarization and photon energy. ${ }^{[8]}$ The definition of the three beamlines and their experimental stations is currently in progress in consultation with the SwissFEL user community. Experiments performed at other soft X-ray FEL facilities around the world have established certain methods as being specifically relevant to chemistry research, and will be considered for development at SwissFEL. Surface chemistry has proven a rich area for soft X-ray FEL research, due to the high absorption cross-section for low energy X-rays which allow them to be surface sensitive. This has allowed experiments to investigate monolayers of molecules, such as $\mathrm{CO}$ and atomic oxygen, on a metal surface and their response to photoexcitation of the metal. ${ }^{[89,90]}$ These measurements represent the first structurally-sensitive experiments able to probe transition states in chemical reactions during catalytically-active processes. ${ }^{[91]}$ A second class of experiments has investigated photochemical processes of species in solution using resonant inelastic X-ray scattering (RIXS) in the soft X-ray regime. This has allowed researchers to follow the most fundamental of chemical processes: bond-breaking and bond-making. By photo-dissociating a $\mathrm{CO}$ ligand off a parent complex (iron pentacarbonyl, $\mathrm{Fe}(\mathrm{CO})_{5}$ ) researchers were able to follow the dissociation and immediate formation of a solvent-molecule complex, and by using simulations were able to suggest an electronic relaxation pathway consistent with their experimental results. ${ }^{[92,93]} \mathrm{A}$ third class of experiments takes advantage of a combination of different probe techniques in a general-purpose experimental chamber, ${ }^{[94]}$ which is capable of electron/ ion coincidence measurements, ${ }^{[95,96]}$ Auger 
electron measurements, ${ }^{[97]}$ and X-ray scattering measurements. ${ }^{[98-100]}$ When used in combination with a variety of sample injectors, including molecular beams, clusters, liquid jets and single-particle injectors, ${ }^{[101]}$ this type of instrument allows for many different kinds of experiments. The development and design of soft X-ray instruments for use at SwissFEL is currently ongoing.

\section{Conclusions}

SwissFEL will begin user operation with two hard X-ray experimental stations in 2018, providing researchers with access to high-intensity femtosecond X-ray pulses that can be used for a broad range of research activities. Experimental station A provides users with instruments that are designed for X-ray spectroscopy and scattering experiments, including serial femtosecond crystallography. In addition to these general features the ESA Prime instrument will also be able to investigate a spectroscopy regime currently not accessible at any other XFEL: the tender X-ray energy range from $2-5 \mathrm{keV}$. This spectral range covers elements such as $\mathrm{S}, \mathrm{P}, \mathrm{Cl}$, and $\mathrm{Ca}$, all of which are biologically relevant, and the 4d metals, which include $\mathrm{Ag}, \mathrm{Pd}, \mathrm{Rh}$, and $\mathrm{Ru}$, many of which are important for catalysis chemistry. The ability to probe these elements and others using resonant X-ray emission spectroscopy (RXES, also sometimes called RIXS) allows researchers to obtain information on both the occupied and unoccupied states of the absorbing species, ${ }^{[102,103]}$ whether that be the HOMO/ LUMO of a molecule or the valence/conduction band of a semiconductor. This information, when combined with the local structure of an excited state, provides an enormous amount of information relevant to chemistry research. Experimental station B is focussed on condensed matter investigations, with the ability to investigate thin films or bulk crystals under a range of different environments using resonant or non-resonant X-ray diffraction. These techniques can be applied to systems such as photoactive molecular crystals ${ }^{[82,83,104]}$ or possibly photochemically-active nanostructured thin films. ${ }^{[105]}$ With these experimental stations, and the development of future instruments at SwissFEL, we hope to enable chemists to perform ground-breaking research at our facility. We are looking forward to working closely with the Swiss chemistry community in the coming years.

\section{Acknowledgments}

The authors would like to acknowledge the ESB-MX project team, Thomas Schmidt, Romain Ganter, Rafael Abela, Gabriel Aeppli, and all the contributions from everyone working on the SwissFEL project at PSI. CJM acknowledges support by the Swiss NSF through the NCCRMUST and the contributions of Jakub Szlachetko and Julien Réhault to the design and concept behind the ESA instruments.

Received: April 26, 2017

[1] R. Jenkins, in 'Encyclopedia of Analytical Chemistry', John Wiley \& Sons, Ltd, 2000.

[2] C. Pellegrini, A. Marinelli, S. Reiche, Rev. Mod. Phys. 2016, 88, 015006.

[3] P. Wilmott, 'An Introduction to Synchrotron Radiation:Techniques and Applications', Wiley, 2011.

[4] S. Tanaka, V. Chernyak, S. Mukamel, Phys. Rev. A 2001, 63, 63405 .

[5] B. D. Patterson, R. Abela, H.-H. Braun, U. Flechsig, R. Ganter, Y. Kim, E. Kirk, A. Oppelt, M. Pedrozzi, S. Reiche, L. Rivkin, T. Schmidt, B. Schmitt, V. N. Strocov, S. Tsujino, A. F. Wrulich, New J. Phys. 2010, 12, 035012 .

[6] R. Ganter, M. Aiba, H.-H. Braun, M. Calvi, P. Heimgartner, H. Joehri, G. Janzi, R. Kobler, F. Loehl, M. Negrazus, E. Prat, L. Patthey, S. Reiche, S. Sanfilippo, U. Schaer, T. Schmidt, L. Schulz, V. Vrankovic, J. Wickstroem, Proc. FEL2013 2013, 263.

[7] W. Gawelda, J. Szlachetko, C. J. Milne, in 'X-Ray Absorption and X-Ray Emission Spectroscopy', John Wiley \& Sons, Ltd, Chichester, UK, 2016, p 637.

[8] E. Prat, M. Calvi, S. Reiche, J. Synchrotron Rad. 2016, 23, 874.

[9] S. Reiche, E. Prat, J. Synchrotron Rad. 2016, 23, 869 .

[10] E. Prat, S. Reiche, Phys. Rev. Lett. 2015, 114, 244801

[11] E. Prat, M. Calvi, R. Ganter, S. Reiche, T. Schietinger, T. Schmidt, J. Synchrotron Rad. 2016, 23,861

[12] R. Follath, U. Flechsig, C. J. Milne, J. Szlachetko, G. Ingold, B. Patterson, L. Patthey, R. Abela, AIP Conf. Proc. 2016, 1741, 020009 .

[13] V. Scagnoli, C. Mazzoli, C. Detlefs, P. Bernard, A. Fondacaro, L. Paolasini, F. Fabrizi, F. De Bergevin, J. Synchrotron Rad. 2009, 16, 778 .

[14] P. Karvinen, S. Rutishauser, A. Mozzanica, D. Greiffenberg, P. N. Juranic, A. Menzel, A. Lutman, J. Krzywinski, D. M. Fritz, H. T. Lemke, M. Cammarata, C. David, Opt. Lett. 2012, 37, 5073 .

[15] M. Makita, P. Karvinen, D. Zhu, P. N. Juranić, J. Grünert, S. Cartier, J. H. Jungmann-Smith, H. T. Lemke, A. Mozzanica, S. Nelson, L. Patthey, M. Sikorski, S. Song, Y. Feng, C. David, Optica 2015, 2, 912.

[16] K. Tono, T. Kudo, M. Yabashi, T. Tachibana, Y. Feng, D. Fritz, J. Hastings, T. Ishikawa, Rev. Sci. Instrum. 2011, 82, 023108.

[17] K. Tiedtke, A. A. Sorokin, U. Jastrow, P. Juranic, S. Kreis, N. Gerken, M. Richter, U. Arp, Y. Feng, D. Nordlund, R. Soufli, M. Fernandez-Perea, L. Juha, P. A. Heimann, B. Nagler, H. J. Lee, S. Mack, M. Cammarata, O. Krupin, M. Messerschmidt, M. Holmes, M. Rowen, W. Schlotter, S. Moeller, J. J. Turner, Opt. Express 2014, 22, 21214

[18] P. N. Juranić, A. Stepanov, R. Ischebeck, V. Schlott, C. Pradervand, L. Patthey, M. Radovic, I. Gorgisyan, L. Rivkin, C. P. Hauri, B. Monoszlai, R. Ivanov, P. Peier, J. Liu, T. Togashi, S. Owada, K. Ogawa, T. Katayama,
M. Yabashi, R. Abela, Opt. Express 2014, 22, 30004.

[19] I. Gorgisyan, R. Ischebeck, C. Erny, A. Dax, L. Patthey, C. Pradervand, L. Sala, C. J. Milne, H. T. Lemke, C. P. Hauri, T. Katayama, S. Owada, M. Yabashi, T. Togashi, R. Abela, L. Rivkin, P. Juranić, Opt Express 2017, 25, 2080.

[20] M. Harmand, R. Coffee, M. R. Bionta, M Chollet, D. French, D. Zhu, D. M. Fritz, H. T. Lemke, N. Medvedev, B. Ziaja, S. Toleikis, M. Cammarata, Nature Photon. 2013, 7, 215.

[21] C. Erny, C. P. Hauri, IUCr, J. Synchrotron Rad. 2016, 23, 1143.

[22] C. Vicario, C. Ruchert, C. P. Hauri, J. Modern Optics 2015, 62, 1480 .

[23] https://www.psi.ch/swissfel/publications

[24] https://www.psi.ch/swissfel/aramis-experimental-station-a

[25] C. J. Milne, T. J. Penfold, M. Chergui, Coord Chem. Rev. 2014, 277, 44.

[26] S. Boutet, L. Lomb, G. J. Williams, T. R. M Barends, A. Aquila, R. B. Doak, U. Weierstall, D. P. DePonte, J. Steinbrener, R. L. Shoeman, M. Messerschmidt, A. Barty, T. A. White, S. Kassemeyer, R. A. Kirian, M. M. Seibert, P. A. Montanez, C. Kenney, R. Herbst, P. Hart, J. Pines, G. Haller, S. M. Gruner, H. T. Philipp, M. W. Tate, M. Hromalik, L. J. Koerner, N. van Bakel, J. Morse, W. Ghonsalves, D. Arnlund, M. J. Bogan, C. Caleman, R. Fromme, C. Y. Hampton, M. S. Hunter, L. C. Johansson, G. Katona, C. Kupitz, M. Liang, A. V. Martin, K. Nass, L. Redecke, F. Stellato, N. Timneanu, D. Wang, N. A. Zatsepin, D. Schafer, J. Defever, R. Neutze, P. Fromme, J. C. H. Spence, H. N. Chapman, I. Schlichting, Science 2012, 337, 362.

[27] T. R. M. Barends, L. Foucar, A. Ardevol, K Nass, A. Aquila, S. Botha, R. B. Doak, K. Falahati, E. Hartmann, M. Hilpert, M. Heinz, M. C. Hoffmann, J. Kofinger, J. E. Koglin, G. Kovacsova, M. Liang, D. Milathianaki, H. T. Lemke, J. Reinstein, C. M. Roome, R. L. Shoeman, G. J. Williams, I. Burghardt, G. Hummer, S. Boutet, I. Schlichting, Science 2015, 350, 445.

[28] M. Calvi, M. Aiba, M. Brügger, S. Danner, R. Ganter, C. Ozkan, T. Schmidt, Proc. FEL2014 2014, 111.

[29] M. Calvi, M. Aiba, M. Brügger, S. Danner, T. Schmidt, R. Ganter, T. Schietinger, R Ischebeck, Proc. FEL2014 2014, 107.

[30] J. C. H. Spence, U. Weierstall, H. N. Chapman, Rep. Prog. Phys. 2012, 75, 102601.

[31] A. Barty, C. Caleman, A. Aquila, N. Timneanu, L. Lomb, T. A. White, J. Andreasson, D. Arnlund, S. Bajt, T. R. M. Barends, M. Barthelmess, M. J. Bogan, C. Bostedt, J. D. Bozek, R. Coffee, N. Coppola, J. Davidsson, D. P. Deponte, R. B. Doak, T. Ekeberg, V. Elser, S. W. Epp, B. Erk, H. Fleckenstein, L. Foucar, P. Fromme, H. Graafsma, L. Gumprecht, J. Hajdu, C. Y. Hampton, R. Hartmann, A. Hartmann, G. Hauser, H. Hirsemann, P. Holl, M. S. Hunter, L. Johansson, S. Kassemeyer, N. Kimmel, R. A. Kirian, M. Liang, F. R. N. C. Maia, E. Malmerberg, S. Marchesini, A. V. Martin, K. Nass, R. Neutze, C. Reich, D. Rolles, B. Rudek, A. Rudenko, H. Scott, I. Schlichting, J. Schulz, M. M. Seibert, R. L. Shoeman, R. G. Sierra, H. Soltau, J. C. H. Spence, F. Stellato, S. Stern, L. Strüder, J. Ullrich, X. Wang, G. Weidenspointner, U. Weierstall, C. B. Wunderer, H. N. Chapman, Nature Photon. 2011, 6, 35.

[32] H. N. Chapman, C. Caleman, N. Timneanu, Phil. Trans. Royal Soc. B: Biol. Sci. 2014, 369, 20130313.

[33] R. Neutze, G. Brändén, G. F. X. Schertler, Curr. Opin. Struc. Biol. 2015, 33, 115. 
[34] U. Bergmann, P. Glatzel, Photosynth. Res. 2009, 102, 255

[35] J. Szlachetko, M. Nachtegaal, E. de Boni, M. Willimann, O. Safonova, J. Sa, G. Smolentsev, M. Szlachetko, J. A. van Bokhoven, J. C. Dousse, J. Hoszowska, Y. Kayser, P. Jagodzinski, A. Bergamaschi, B. Schmitt, C. David, A. Lücke, Rev. Sci. Instrum. 2012, 83, 103105.

[36] J. Szlachetko, C. J. Milne, J. Hoszowska, J. C. Dousse, W. Błachucki, J. Sa, Y. Kayser, M. Messerschmidt, R. Abela, S. Boutet, C. David, G. Williams, M. Pajek, B. D. Patterson, G. Smolentsev, J. A. van Bokhoven, M. Nachtegaal, Struct. Dyn. 2014, 1, 021101.

[37] J. Szlachetko, M. Nachtegaal, J. Sa, J.-C. Dousse, J. Hoszowska, E. Kleymenov, M. Janousch, O. V. Safonova, C. König, J. A. van Bokhoven, Chem. Commun. 2012, 48, 10898.

[38] J. H. Jungmann-Smith, A. Bergamaschi, M. Brückner, S. Cartier, R. Dinapoli, D. Greiffenberg, A. Jaggi, D. Maliakal, D. Mayilyan, K. Medjoubi, D. Mezza, A. Mozzanica, M. Ramilli, C. Ruder, L. Schädler, B. Schmitt, X. Shi, G. Tinti, Rev. Sci. Instrum. $\mathbf{2 0 1 5}, 86,123110$.

[39] J. H. Jungmann-Smith, A. Bergamaschi, S. Cartier, R. Dinapoli, D. Greiffenberg, I. Johnson, D. Maliakal, D. Mezza, A. Mozzanica, C. Ruder, L. Schaedler, B. Schmitt, X. Shi, G. Tinti, J. Inst. 2014, 9, P12013.

[40] A. Mozzanica, A. Bergamaschi, S. Cartier, R. Dinapoli, D. Greiffenberg, I. Johnson, J. Jungmann, D. Maliakal, D. Mezza, C. Ruder, L. Schaedler, B. Schmitt, X. Shi, G. Tinti, J. Inst. 2014, 9, C05010.

[41] K. Haldrup, W. Gawelda, R. Abela, R. Alonso-Mori, U. Bergmann, A. Bordage, M. Cammarata, S. E. Canton, A. O. Dohn, T. B. van Driel, D. M. Fritz, A. Galler, P. Glatzel, T. Harlang, K. S. Kjaer, H. T. Lemke, K. B. Møller, Z. Németh, M. Pápai, N. Sas, J. Uhlig, D. Zhu, G. Vankó, V. Sundstrom, M. M. Nielsen, C. Bressler, J. Phys. Chem. B 2016, 120, 1158.

[42] S. E. Canton, K. S. Kjaer, G. Vankó, T. B. van Driel, S.-I. Adachi, A. Bordage, C. Bressler, P. Chabera, M. Christensen, A. O. Dohn, A. Galler, W. Gawelda, D. Gosztola, K. Haldrup, T. Harlang, Y. Liu, K. B. Møller, Z. Németh, S. Nozawa, M. Pápai, T. Sato, T. Sato, K. Suarez-Alcantara, T. Togashi, K. Tono, J. Uhlig, D. A. Vithanage, K. Wärnmark, M. Yabashi, J. Zhang, V. Sundstrom, M. M. Nielsen, Nature Commun. 2015, 6, 6359.

[43] J. Kern, R. Alonso-Mori, R. Tran, J. Hattne, R. J. Gildea, N. Echols, C. Glockner, J. Hellmich, H. Laksmono, R. G. Sierra, B. LassalleKaiser, S. Koroidov, A. Lampe, G. Han, S. Gul, D. DiFiore, D. Milathianaki, A. R. Fry, A. Miahnahri, D. W. Schafer, M. Messerschmidt, M. M. Seibert, J. E. Koglin, D. Sokaras, T. C. Weng, J. Sellberg, M. J. Latimer, R. W. Grosse-Kunstleve, P. H. Zwart, W. E. White, P. Glatzel, P. D. Adams, M. J. Bogan, G. J. Williams, S. Boutet, J. Messinger, A. Zouni, N. K. Sauter, V. K. Yachandra, U. Bergmann, J. Yano, Science 2013, 340, 491.

[44] J. Kern, J. Hattne, R. Tran, R. Alonso-Mori, H. Laksmono, S. Gul, R. G. Sierra, J. Rehanek, A. Erko, R. Mitzner, P. Wernet, U. Bergmann, N. K. Sauter, V. Yachandra, J. Yano, Phil. Trans. Royal Soc. B: Biol. Sci. 2014, 369, 20130590.

[45] U. Weierstall, D. James, C. Wang, T. A. White, D. Wang, W. Liu, J. C. H. Spence, R. B. Doak, G. Nelson, P. Fromme, R. Fromme, I Grotjohann, C. Kupitz, N. A. Zatsepin, H. Liu, S. Basu, D. Wacker, G. W. Han, V. Katritch, S. E. B. Boutet, M. Messerschmidt, G. J. Williams, J. E. Koglin, M. M. Seibert, M. Klinker, C. Gati,
R. L. Shoeman, A. Barty, H. N. Chapman, R. A. Kirian, K. R. Beyerlein, R. C. Stevens, D. Li, S. T. A. Shah, N. Howe, M. Caffrey, V. Cherezov, Nature Commun. 2014, 5, 1.

[46] U. Weierstall, J. C. H. Spence, R. B. Doak, Rev. Sci. Instrum. 2012, 83, 035108.

[47] G. Ingold, J. Rittmann, P. Beaud, M. Divall, C. Erny, U. Flechsig, R. Follath, C. P. Hauri, S. Hunziker, P. Juranic, A. Mozzanica, B. Pedrini, L. Sala, L. Patthey, B. D. Patterson, R. Abela, AIP Conf. Proc. 2016, 1741, 030039.

[48] P. Beaud, S. L. Johnson, E. Vorobeva, C. J. Milne, A. Caviezel, S. O. Mariager, R. A. De Souza, U. Staub, G. Ingold, Chimia 2011, 65, 308.

[49] P. Beaud, S. L. Johnson, A. Streun, R. Abela, D. Abramsohn, D. Grolimund, F. Krasniqi, T. Schmidt, V. Schlott, G. Ingold, Phys. Rev. Lett. 2007, 99, 174801.

[50] G. Ingold, R. Abela, P. Beaud, S. L. Johnson, U. Staub, Z. Kristallogr. 2008, 223, 292.

[51] T. Kubacka, J. A. Johnson, M. C. Hoffmann, C. Vicario, S. de Jong, P. Beaud, S. Grübel, S. W. Huang, L. Huber, L. Patthey, Y. D. Chuang, J. J. Turner, G. L. Dakovski, W. S. Lee, M. P. Minitti, W. Schlotter, R. G. Moore, C. P. Hauri, S. M. Koohpayeh, V. Scagnoli, G. Ingold, S. L. Johnson, U. Staub, Science 2014, 343, 1333.

[52] M. S. Hunter, B. Segelke, M. Messerschmidt, G. J. Williams, N. A. Zatsepin, A. Barty, W. H. Benner, D. B. Carlson, M. Coleman, A. Graf, S. P. Hau-Riege, T. Pardini, M. M. Seibert, J. Evans, S. Boutet, M. Frank, Sci. Rep. 2014, 4, 6026.

[53] J. A. Wojdyla, E. Panepucci, I. Martiel, S Ebner, C.-Y. Huang, M. Caffrey, O. Bunk, M. Wang, J. Appl. Crystallogr. 2016, 49, 944.

[54] K. Hirata, K. Shinzawa-Itoh, N. Yano, S. Takemura, K. Kato, M. Hatanaka, K. Muramoto, T. Kawahara, T. Tsukihara, E. Yamashita, K. Tono, G. Ueno, T. Hikima, H. Murakami, Y. Inubushi, M. Yabashi, T. Ishikawa, M. Yamamoto, T. Ogura, H. Sugimoto, J.-R. Shen, S. Yoshikawa, H. Ago, Nat. Meth. 2014, 1, 734 .

[55] M. Suga, F. Akita, K. Hirata, G. Ueno, H. Murakami, Y. Nakajima, T. Shimizu, K. Yamashita, M. Yamamoto, H. Ago, J.-R. Shen, Nature 2015, 517, 99.

[56] A. H. Zewail, Science 1988, 242, 1645.

[57] H. Ihee, Acc. Chem. Res. 2009, 42, 356,.

[58] K. Haldrup, M. Christensen, M. M. Nielsen, Acta Crystallogr. A 2010, 66, 261.

[59] A. Hauser, Top. Curr. Chem. 2004, 234, 155.

[60] A. Hauser, Top. Curr. Chem. 2004, 233, 49.

[61] W. Gawelda, A. Cannizzo, V.-T. Pham, F. van Mourik, C. Bressler, M. Chergui, J. Am. Chem. Soc. 2007, 129, 8199.

[62] W. Gawelda, V.-T. Pham, M. Benfatto, Y. Zaushitsyn, M. Kaiser, D. Grolimund, S. L. Johnson, R. Abela, A. Hauser, C. Bressler, M. Chergui, Phys. Rev. Lett. 2007, 98, 057401.

[63] C. Bressler, C. J. Milne, V. T. Pham, A. El Nahhas, R. M. van der Veen, W. Gawelda, S. L. Johnson, P. Beaud, D. Grolimund, M. Kaiser, C. N. Borca, G. Ingold, R. Abela, M. Chergui, Science 2009, 323, 489.

[64] C. Consani, M. Prémont-Schwarz, A. El Nahhas, C. Bressler, F. van Mourik, A. Cannizzo, M. Chergui, Angew. Chem. Int. Ed. 2009, 48, 7184.

[65] G. Vankó, P. Glatzel, V.-T. Pham, R. Abela, D. Grolimund, C. N. Borca, S. L. Johnson, C. J. Milne, C. Bressler, Angew. Chem. Int. Ed. 2010, 49, 5910.

[66] G. Vankó, T. Neisius, G. Molnar, F. Renz, S. Karpati, A. Shukla, F. M. F. de Groot, J. Phys. Chem. B 2006, 110, 11647.

[67] A. Cannizzo, C. J. Milne, C. Consani, W. Gawelda, C. Bressler, F. van Mourik, M. Chergui, Coord. Chem. Rev. 2010, 254, 2677.
[68] M.-E. Moret, I. Tavernelli, M. Chergui, U. Rothlisberger, Chem-Eur. J. 2010, 16, 5889.

[69] K. Haldrup, G. Vankó, W. Gawelda, A. Galler, G. Doumy, A. M. March, E. P. Kanter, A. Bordage, A. Dohn, T. B. van Driel, K. S. Kjær, H. T. Lemke, S. E. Canton, J. Uhlig, V. Sundstrom, L. Young, S. H. Southworth, M. M. Nielsen, C. Bressler, J. Phys. Chem. A 2012, 116, 9878 .

[70] H. T. Lemke, C. Bressler, L. X. Chen, D. M. Fritz, K. J. Gaffney, A. Galler, W. Gawelda, K. Haldrup, R. W. Hartsock, H. Ihee, J. Kim, K. H. Kim, J. H. Lee, M. M. Nielsen, A. B. Stickrath, W. Zhang, D. Zhu, M. Cammarata, J. Phys. Chem. A 2013, 117, 735.

[71] L. M. Lawson Daku, A. Hauser, J. Phys. Chem. Lett. 2010, 1, 1830.

[72] M. R. Bionta, H. T. Lemke, J. P. Cryan, J. M. Glownia, C. Bostedt, M. Cammarata, J. C. Castagna, Y. Ding, D. M. Fritz, A. R. Fry, J. Krzywinski, M. Messerschmidt, S. Schorb, M. Swiggers, R. Coffee, Opt. Express 2011, 19, 21855.

[73] G. Aübock, M. Chergui, Nature Chem. 2015, 7, 629.

[74] E. Biasin, T. B. van Driel, K. S. Kjaer, A. O. Dohn, M. Christensen, T. Harlang, P. Chabera, Y. Liu, J. Uhlig, M. Pápai, Z. Németh, R. Hartsock, W. Liang, J. Zhang, R. AlonsoMori, M. Chollet, J. M. Glownia, S. Nelson, D. Sokaras, T. A. Assefa, A. Britz, A. Galler, W. Gawelda, C. Bressler, K. J. Gaffney, H. T. Lemke, K. B. Møller, M. M. Nielsen, V. Sundstrom, G. Vankó, K. Wärnmark, S. E. Canton, K. Haldrup, Phys. Rev. Lett. 2016, 117, 013002.

[75] R. W. Hartsock, A. O. Dohn, T. Harlang, M. Chollet, M. Christensen, W. Gawelda, N. E. Henriksen, J. G. Kim, K. Haldrup, K. H. Kim, H. Ihee, J. Kim, H. T. Lemke, Z. Sun, V. S. O. m, W. Zhang, D. Zhu, T. B. van Driel, K. S. K. A. r, K. B. M. O. ller, M. M. Nielsen, K. J. Gaffney, Nature Commun. 2016, 7, 1.

[76] M. Levantino, G. Schiró, H. T. Lemke, G. Cottone, J. M. Glownia, D. Zhu, M. Chollet, H. Ihee, A. Cupane, M. Cammarata, Nature Commun. 2015, 6, page.

[77] M. Levantino, H. T. Lemke, G. Schiró, M. Glownia, A. Cupane, M. Cammarata, Struct. Dyn. 2015, 2, 041713.

[78] D. Arnlund, L. C. Johansson, C. Wickstrand, A. Barty, G. J. Williams, E. Malmerberg, J. Davidsson, D. Milathianaki, D. P. Deponte, R. L. Shoeman, D. Wang, D. James, G. Katona, S. Westenhoff, T. A. White, A. Aquila, S. Bari, P. Berntsen, M. Bogan, T. B. van Driel, R. B. Doak, K. S. Kjær, M. Frank, R. Fromme, I. Grotjohann, R. Henning, M. S. Hunter, R. A. Kirian, I. Kosheleva, C. Kupitz, M. Liang, A. V. Martin, M. M. Nielsen, M. Messerschmidt, M. M. Seibert, J. Sjohamn, F. Stellato, U. Weierstall, N. A. Zatsepin, J. C. H. Spence, P. Fromme, I. Schlichting, S. Boutet, G. Groenhof, H. N. Chapman, R. Neutze, Nat. Meth. 2014, 11, 923.

[79] In 2018 five facilities worldwide will have instruments capable of performing these kinds of experiments: LCLS (Stanford, CA, USA), SACLA (Spring-8, Japan), PAL-FEL (Pohang, Korea), European XFEL (Hamburg, German), and SwissFEL (Villigen-PSI, Switzerland).

[80] M. P. Minitti, J. M. Budarz, A. Kirrander, J. S. Robinson, D. Ratner, T. J. Lane, D. Zhu, J. M. Glownia, M. Kozina, H. T. Lemke, M. Sikorski, Y. Feng, S. Nelson, K. Saita, B. Stankus, T. Northey, J. B. Hastings, P. M. Weber, Phys. Rev. Lett. 2015, 114, 255501.

[81] J. M. Budarz, M. P. Minitti, D. V. CoferShabica, B. Stankus, A. Kirrander, J. B. Hastings, P. M. Weber, J. Phys. B: At. Mol. Opt. Phys. 2016, 49, 034001. 
[82] P. Coppens, Struct. Dyn. 2017, 4, 032102.

[83] M. Cammarata, R. Bertoni, M. Lorenc, H. Cailleau, S. Di Matteo, C. Mauriac, S. F. Matar, H. T. Lemke, M. Chollet, S. Ravy, C. Laulhé, J.-F. Létard, E. Collet, Phys. Rev. Lett. 2014, 113, 227402

[84] M. Sugahara, E. Mizohata, E. Nango, M Suzuki, T. Tanaka, T. Masuda, R. Tanaka, T. Shimamura, Y. Tanaka, C. Suno, K. Ihara, D. Pan, K. Kakinouchi, S. Sugiyama, M. Murata, T. Inoue, K. Tono, C. Song, J. Park, T. Kameshima, T. Hatsui, Y. Joti, M. Yabashi, S Iwata, Nat. Meth. 2014, 12, 61 .

[85] C. E. Conrad, S. Basu, D. James, D. Wang, A. Schaffer, S. Roy-Chowdhury, N. A Zatsepin, A. Aquila, J. Coe, C. Gati, M. S. Hunter, J. E. Koglin, C. Kupitz, G. Nelson, G. Subramanian, T. A. White, Y. Zhao, J. Zook, S. Boutet, V. Cherezov, J. C. H. Spence, R. Fromme, U. Weierstall, P. Fromme, IUCrJ 2015, 2, 421

[86] P. Nogly, V. Panneels, G. Nelson, C. Gati, T. Kimura, C. J. Milne, D. Milathianaki, M. Kubo, W. Wu, C. Conrad, J. Coe, R. Bean, Y. Zhao, P. Båth, R. Dods, R. Harimoorthy, K R. Beyerlein, J. Rheinberger, D. James, D. Deponte, C. Li, L. Sala, G. J. Williams, M. S. Hunter, J. E. Koglin, P. Berntsen, E. Nango, S Iwata, H. N. Chapman, P. Fromme, M. Frank, R. Abela, S. Boutet, A. Barty, T. A. White, U. Weierstall, J. Spence, R. Neutze, G. Schertler, J. Standfuss, Nature Commun. 2016, 7, 12314

[87] E. Nango, A. Royant, M. Kubo, T. Nakane, C. Wickstrand, T. Kimura, T. Tanaka, K. Tono, C. Song, R. Tanaka, T. Arima, A. Yamashita, J. Kobayashi, T. Hosaka, E. Mizohata, P. Nogly, M. Sugahara, D. Nam, T. Nomura, T. Shimamura, D. Im, T. Fujiwara, Y. Yamanaka, B. Jeon, T. Nishizawa, K. Oda, M. Fukuda, R Andersson, P. Båth, R. Dods, J. Davidsson, S. Matsuoka, S. Kawatake, M. Murata, O. Nureki, S. Owada, T. Kameshima, T. Hatsui, Y. Joti, G. Schertler, M. Yabashi, A.-N. Bondar, J. Standfuss, R. Neutze, S. Iwata, Science 2016, 354, 1552.

[88] K. R. Beyerlein, C. Jooss, A. Barty, R. Bean, S. Boutet, S. S. Dhesi, R. B. Doak, M. Först, L. Galli, R. A. Kirian, J. Kozak, M. Lang, R. Mankowsky, M. Messerschmidt, J. C. H. Spence, D. Wang, U. Weierstall, T. A. White, G. J. Williams, O. Yefanov, N. A. Zatsepin, A Cavalleri, H. N. Chapman, Powder Diff. 2015, $30, \mathrm{~S} 25$.

[89] H. Ostrom, H. Öberg, H. Xin, J. LaRue, M. Beye, M. Dell'Angela, J. Gladh, M. L. $\mathrm{Ng}$, J. A. Sellberg, S. Kaya, G. Mercurio, D. Nordlund, M. Hantschmann, F. Hieke, D. Kuehn, W. F. Schlotter, G. L. Dakovski, J. J. Turner, M. P. Minitti, A. Mitra, S. P. Moeller, A. Foehlisch, M. Wolf, W. Wurth, M. Persson, J. K. Nørskov, F. Abild-Pedersen, H. Ogasawara, L. G. M. Pettersson, A. Nilsson, Science 2015, 347, 978.

[90] M. Dell'Angela, T. Anniyev, M. Beye, R. Coffee, A. Föhlisch, J. Gladh, T. Katayama, S. Kaya, O. Krupin, J. LaRue, A. Møgelhøj, D. Nordlund, J. K. Nørskov, H. Öberg, H.
Ogasawara, H. Ostrom, L. G. M. Pettersson, W. F. Schlotter, J. A. Sellberg, F. Sorgenfrei, J. J. Turner, M. Wolf, W. Wurth, A. Nilsson, Science 2013, 339, 1302.

[91] A. Nilsson, J. LaRue, H. Öberg, H. Ogasawara, M. Dell'Angela, M. Beye, H. Ostrom, J. Gladh, J. K. Nørskov, W. Wurth, F. Abild-Pedersen, L. G. M. Pettersson, Chem. Phys. Lett. 2017, 675, 145.

[92] P. Wernet, K. Kunnus, I. Josefsson, I Rajkovic, W. Quevedo, M. Beye, S. Schreck, S. Grübel, M. Scholz, D. Nordlund, W. Zhang, R. W. Hartsock, W. F. Schlotter, J. J. Turner, B. Kennedy, F. Hennies, F. M. F. de Groot, K. J. Gaffney, S. Techert, M. Odelius, A. Föhlisch, Nature 2015, 520, 78

[93] K. Kunnus, I. Josefsson, I. Rajkovic, S. Schreck, W. Quevedo, M. Beye, C. Weniger, S. Grübel, M. Scholz, D. Nordlund, W. Zhang, R. W. Hartsock, K. J. Gaffney, W. F. Schlotter, J. J. Turner, B. Kennedy, F. Hennies, F. M. F. de Groot, S. Techert, M. Odelius, P. Wernet, A. Föhlisch, Struct. Dyn. 2016, 3, 043204.

[94] L. Strüder, S. Epp, D. Rolles, R. Hartmann, P. Holl, G. Lutz, H. Soltau, R. Eckart, C. Reich, K. Heinzinger, C. Thamm, A. Rudenko, F Krasniqi, K.-U. Kühnel, C. Bauer, C.-D. Schröter, R. Moshammer, S. Techert, D. Miessner, M. Porro, O. Hälker, N. Meidinger, N. Kimmel, R. Andritschke, F. Schopper, G. Weidenspointner, A. Ziegler, D. Pietschner, S. Herrmann, U. Pietsch, A. Walenta, W. Leitenberger, C. Bostedt, T. Möller, D. Rupp, M. Adolph, H. Graafsma, H. Hirsemann, K. Gärtner, R. Richter, L. Foucar, R. L. Shoeman, I. Schlichting, J. Ullrich, Nuclear Inst. Meth. Phys. Res. A 2010, 614, 483.

[95] C. E. Liekhus-Schmaltz, I. Tenney, T. Osipov, A. Sanchez-Gonzalez, N. Berrah, R. Boll, C. Bomme, C. Bostedt, J. D. Bozek, S. Carron, R. Coffee, J. Devin, B. Erk, K. R. Ferguson, R. W. Field, L. Foucar, L. J. Frasinski, J. M. Glownia, M. Gühr, A. Kamalov, J. Krzywinski, H. Li, J. P. Marangos, T. J. Martinez, B. K. McFarland, S. Miyabe, B. Murphy, A. Natan, D. Rolles, A. Rudenko, M. Siano, E. R. Simpson, L. Spector, M. Swiggers, D. Walke, S. Wang, T. Weber, P. H. Bucksbaum, V. S. Petrovic, Nature Commun. 2015, 6, 8199.

[96] R. Boll, B. Erk, R. Coffee, S. Trippel, T. Kierspel, C. Bomme, J. D. Bozek, M. Burkett, S. Carron, K. R. Ferguson, L. Foucar, J. Küpper, T. Marchenko, C. Miron, M. Patanen, T. Osipov, S. Schorb, M. Simon, M. Swiggers, S. Techert, K. Ueda, C. Bostedt, D. Rolles, A. Rudenko, Struct. Dyn. 2016, 3, 043207.

[97] B. K. McFarland, J. P. Farrell, S. Miyabe, F. Tarantelli, A. Aguilar, N. Berrah, C. Bostedt, J. D. Bozek, P. H. Bucksbaum, J. C. Castagna, R. N. Coffee, J. P. Cryan, L. Fang, R. Feifel, K. J. Gaffney, J. M. Glownia, T. J. Martinez, M. Mucke, B. Murphy, A. Natan, T. Osipov, V. S. Petrovic, S. Schorb, T. Schultz, L. S. Spector, M. Swiggers, I. Tenney, S. Wang, J. L. White, W. White, M. Gühr, Nature Commun. 2014, 5 , 4235 .
[98] T. Ekeberg, M. Svenda, C. Abergel, F. R. N. C. Maia, V. Seltzer, J.-M. Claverie, M. Hantke, O. Jönsson, C. Nettelblad, G. van der Schot, M. Liang, D. P. Deponte, A. Barty, M. M. Seibert, B. Iwan, I. Andersson, N. D. Loh, A. V. Martin, H. Chapman, C. Bostedt, J. D. Bozek, K. R. Ferguson, J. Krzywinski, S. W. Epp, D. Rolles, A. Rudenko, R. Hartmann, N. Kimmel, J. Hajdu, Phys. Rev. Lett. 2015, 114, 098102.

[99] G. van der Schot, M. Svenda, F. R. N. C. Maia, M. Hantke, D. P. Deponte, M. M. Seibert, A. Aquila, J. Schulz, R. Kirian, M. Liang, F. Stellato, B. Iwan, J. Andreasson, N. Timneanu, D. Westphal, F. N. Almeida, D. Odić, D. Hasse, G. H. Carlsson, D. S. D. Larsson, A. Barty, A. V. Martin, S. Schorb, C. Bostedt, J. D. Bozek, D. Rolles, A. Rudenko, S. Epp, L. Foucar, B. Rudek, R. Hartmann, N. Kimmel, P. Holl, L. Englert, N. T. Duane Loh, H. N. Chapman, I. Andersson, J. Hajdu, T. Ekeberg, Nature Commun. 2015, 6, 5704.

[100] M. M. Seibert, T. Ekeberg, F. R. N. C. Maia M. Svenda, J. Andreasson, O. Jönsson, D. Odić, B. Iwan, A. Rocker, D. Westphal, M. Hantke, D. P. Deponte, A. Barty, J. Schulz, L. Gumprecht, N. Coppola, A. Aquila, M. Liang, T. A. White, A. Martin, C. Caleman, S. Stern, C. Abergel, V. Seltzer, J.-M. Claverie, C. Bostedt, J. D. Bozek, S. Boutet, A. A Miahnahri, M. Messerschmidt, J. Krzywinski, G. Williams, K. O. Hodgson, M. J. Bogan, C. Y. Hampton, R. G. Sierra, D. Starodub, I Andersson, S. Bajt, M. Barthelmess, J. C. H. Spence, P. Fromme, U. Weierstall, R. Kirian, M. Hunter, R. B. Doak, S. Marchesini, S. P. Hau-Riege, M. Frank, R. L. Shoeman, L. Lomb, S. W. Epp, R. Hartmann, D. Rolles, A Rudenko, C. Schmidt, L. Foucar, N. Kimmel, P. Holl, B. Rudek, B. Erk, A. Hömke, C. Reich, D. Pietschner, G. Weidenspointner, L. Strüder, G. Hauser, H. Gorke, J. Ullrich, I. Schlichting, S. Herrmann, G. Schaller, F. Schopper, H. Soltau, K.-U. Kühnel, R. Andritschke, C.-D. Schröter, F. Krasniqi, M. Bott, S. Schorb, D. Rupp, M. Adolph, T. Gorkhover, H. Hirsemann, G. Potdevin, H. Graafsma, B. Nilsson, H. N. Chapman, J. Hajdu, Nature 2011, 469, 78.

[101] R. A. Kirian, S. Awel, N. Eckerskorn, H Fleckenstein, M. Wiedorn, L. Adriano, S. Bajt, M. Barthelmess, R. Bean, K. R. Beyerlein, L. M. G. Chavas, M. Domaracky, M. Heymann, D. A. Horke, J. Knoska, M. Metz, A. Morgan, D. Oberthuer, N. Roth, T. Sato, P. L. Xavier, O. Yefanov, A. V. Rode, J. Küpper, H. N. Chapman, Struct. Dyn. 2015, 2, 041717.

[102] J. Szlachetko, M. Pichler, D. Pergolesi, J. Sa, T. Lippert, RSC Adv. 2014, 4, 11420.

[103] J. Szlachetko, J. Sa, CrystEng Comm 2013, 15, 2583.

[104] R. Bertoni, M. Lorenc, H. Cailleau, A Tissot, J. Laisney, M.-L. Boillot, L. Stoleriu, A. Stancu, C. Enachescu, E. Collet, Nature Mater. 2016, 15, 606.

[105] X. Chen, C. Li, M. Grätzel, R. Kostecki, S. S. Mao, Chem. Soc. Rev. 2012, 41, 7909. 